\title{
STUDI PENGEMBANGAN PENYEDIAAN AIR MINUM BALAI SELASA, KECAMATAN RANAH PESISIR KABUPATEN PESISIR SELATAN
}

\author{
Slamet Raharjo dan Dwi Laksono \\ Jurusan Teknik Lingkungan Universitas Andalas \\ Email: sraharjo@ft.unand.ac.id
}

\begin{abstract}
ABSTRAK
Sistem Penyediaan Air Minum (SPAM) Perpipaan di Kecamatan Ranah Pesisir, Kabupaten Pesisir Selatan diselenggarakan oleh PDAM Unit Balai Selasa, dengan tingkat pelayanan baru 11,5\%. Intake eksisting hanya berupa pipa bersaringan berkapasitas $10 \mathrm{l} / \mathrm{detik}$, namun mengalami kerusakan dan kendala pada musim kemarau. Instalasi pengolahan air hanya berupa Saringan Pasir Lambat (SPL) berkapasitas 3,5 l/detik, namun mengalami kerusakan struktur akibat gempa sehingga tidak difungsikan lagi. Tingkat pelayanan harus ditingkatkan sesuai dengan yang ditargetkan MDG's dan Depkimpraswil yaitu 80 \%. Dalam kegiatan ini disusun suatu studi kebutuhan dan penyediaan air minum untuk daerah pelayanan Nagari Palangai Gadang, Nagari Palangai, Nyiur Malambai Palangai dan Nagari VIII Palangai. Proyeksi kebutuhan air minum diprediksi untuk 17 tahun ke depan (2013-2030) dengan tingkat pelayanan 2030 sebesar $25 \%$. Total kebutuhan air minum ratarata, maksimum dan puncak berurutan adalah 11,84 l/dtk, 14,21 l/dtk dan 21,31 l/dtk. Dengan tidak beroperasinya unit pengolahan SPL, maka dibutuhkan pembangunan Instalasi Pengolahan Air Minum sebesar 15 l/det pada tahun 2013. Sumber air baku yang digunakan adalah Sungai Batang Palangai dengan mengunakan intake kanal berkapasitas $15 \mathrm{l} /$ det. Hasil analisa air menyimpulkan bahwa parameter yang melebihi BM sesuai Permenkes No.492/MenKes/PER/IV/2010 hanya parameter bakteriologis, sehingga dibutuhkan unit-unit pengolahan meliputi Unit Desinfeksi yang dibantu dengan Unit Saringan Pasir Cepat (SPC) untuk menurunkan kekeruhan pada musim hujan.
\end{abstract}

Kata kunci: Kecamatan Ranah Pesisir, SPAM Perpipaan PDAM, tingkat pelayanan.

\section{ABSTRACT}

Water Supply System (SPAM) Piping in Ranah Pesisir District, Pesisir Selatan taps held by Balai Selasa Unit of Water work, with a new service level of 11.5\%. Existing intake filtered pipe with a capacity of $10 \mathrm{l} / \mathrm{sec}$, but the damage and constraints in the dry season. Water treatment plant is only a Slow Sand Filter (SPL) with a capacity of $3.5 \mathrm{l} / \mathrm{sec}$, but suffered from structural damage from the earthquake so it does not function anymore. Service levels should be increased in accordance with the $M D G$ 's target of $80 \%$ and Household and Infrastructure Department. In this activity, conducted the study of needs and provision of drinking water to the service area Palangai Tower Nagari, Nagari Palangai, Nyiur Malambai Palangai and Nagari Palangai VIII. Projected water consumption is predicted for the next 17 years (2013-2030) with a service level of $25 \%$ in 2030. Total water consumption on average, maximum and peaks consecutively are $11.84 \mathrm{l} / \mathrm{sec}, 14.21 \mathrm{l} / \mathrm{sec}$ and 21.31 l/sec. With no operation processing slow sand filtration unit, the required Water Treatment Plant of 15 $l / s$ in 2013. The source of raw water used is Batang Palangai using the canal intake capacity of $15 \mathrm{l} / \mathrm{s}$. The results of the water analysis concludes that the appropriate parameters exceed Permenkes BM 492/Menkes/Per/IV/2010 was only on bacteriological parameters, thus requiring processing units of Disinfection Unit assisted with Rapid Sand Filter Unit (SPC) to reduce the turbidity of the season rain.

Keywords: Ranah Pesisir District, SPAM Piping taps, service level 


\section{PENDAHULUAN}

\section{Latar Belakang}

Ranah Pesisir merupakan salah satu kecamatan yang ada di Kabupaten Pesisir Selatan dengan jumlah penduduk 30.404 jiwa dengan luas daerah mencapai 564,39 $\mathrm{km}^{2}$ (Biro Pusat Statistik, 2012). Kecamatan ini merupakan satu dari tiga kecamatan dengan pertumbuhan penduduk tertinggi di Kabupaten Pesisir Selatan sehingga menjadi prioritas pengembangan pemukiman. Penyediaan air minum di Kecamatan Ranah Pesisir saat ini dikelola oleh PDAM Unit Balai Selasa dengan tingkat pelayanannya baru mencapai 11,5\%. Disamping PDAM, penyediaan air minum juga dibantu oleh adanya program pemerintah yang berbasis masyarakat, yaitu PAMSIMAS (Penyediaan Air Minum dan Sanitasi Berbasis Masyarakat). Pada kenyataannya program berbasis masyarakat ini memiliki beberapa kekurangan seperti kurangnya kepedulian masyarakat dalam merawat fasilitasnya sehingga umur pemakaiannya tidak lama.

Berdasarkan Rencana Induk SPAM (RISPAM) Kabupaten Pesisir Selatan 2012 terkait dengan target Millennium Development Goals (MDG's) yang telah diratifikasi menyebutkan bahwa minimal 80 $\%$ jumlah penduduk mendapatkan pelayanan air minum yang memadai pada tahun 2015 . Menindaklanjuti kebijakan nasional tersebut Kabupaten Pesisir Selatan menyiapkan visi, misi dan langkah konkret dalam pembangunan yang tertuang dalam Rencana Tata Ruang Wilayah (RTRW) Kabupaten Pesisir Selatan Tahun 2010-2030 yang mengarahkan pengembangan penyediaan air bersih untuk daerah-daerah padat penduduk dan pusat-pusat pemukiman (Bappeda Kab Pesisir Selatan, 2009).

Sehubungan dengan permasalahan di atas, perlu dilakukan studi kebutuhan dan penyediaan air minum untuk Kecamatan Ranah Pesisir Kabupaten Pesisir Selatan.

\section{Maksud dan Tujuan}

1. Maksud dari Tugas Akhir ini adalah sebagai pedoman bagi pihak-pihak terkait dalam pengembangan SPAM Kecamatan Ranah Pesisir Kabupaten Pesisir Selatan;
2. Tujuannya adalah untuk mempersiapkan data kebutuhan air minum, daerah pelayanan, sistem transmisi dan distribusi yang dibutuhkan untuk menyusun rencana rinci (Detail Design) SPAM Kecamatan Ranah Pesisir Kabupaten Pesisir Selatan.

\section{Gambaran Umum Daerah Studi}

\section{Fisik dan Kependudukan}

Kecamatan Ranah Pesisir terletak pada $100^{\circ}$ $45^{\prime}-101^{0} 07^{\prime}$ Bujur Timur dan $1^{0} 27,70^{\prime}$ $1^{0} 58,53$ ' Lintang Selatan, dengan batas wilayah sebagai berikut:

- Utara: Kecamatan Lengayang;

- Selatan: Kec. Linggo Sari Baganti;

- Barat : Samudera Indonesia;

- Timur : Bukit Kabupaten Solok.

Peta administrasi lokasi studi dapat dilihat pada Gambar 1.

Secara umum bagian barat wilayah merupakan dataran rendah dan semakin ke timur semakin tinggi. Kemiringan lahan berkisar antara $0 \%-2 \%$ sampai kemiringan $>40 \%$.

Kecamatan Ranah Pesisir dilalui oleh dua buah sungai, yaitu Sungai Batang Palangai Gadang dan Sungai Batang Palangai Ketek serta memiliki luas DAS (Daerah Aliran Sungai) 498,86 $\mathrm{Km}^{2}$. Sungai Batang Palangai Gadang memiliki panjang sungai $51,11 \mathrm{Km}$ dan debit minimum sungai 40 1/det, sedangkan Batang Palangai Ketek memiliki debit minimum 20 1/det.

Kecamatan Ranah Pesisir Kabupaten Pesisir Selatan beriklim tropis dengan temperatur harian berkisar antara $23{ }^{\circ} \mathrm{C}-32{ }^{\circ} \mathrm{C}$. Ratarata curah hujan sebesar $257 \mathrm{~mm}$ pertahun, hampir merata sepanjang tahun dengan banyak hari hujan berkisar antara 18-102 hari hujan. Kelembapan udara rata-rata sekitar $80 \%$.

Lahan di Kecamatan Ranah Pesisir telah dimanfaatkan untuk sawah, ladang, kebun dan lainnya seperti pemukiman, fasilitas pendidikan, fasilitas kesehatan, dan fasilitas perdagangan. Lahan untuk pemukiman sebesar $1,21 \%$ atau $7 \mathrm{~km}^{2}$. 


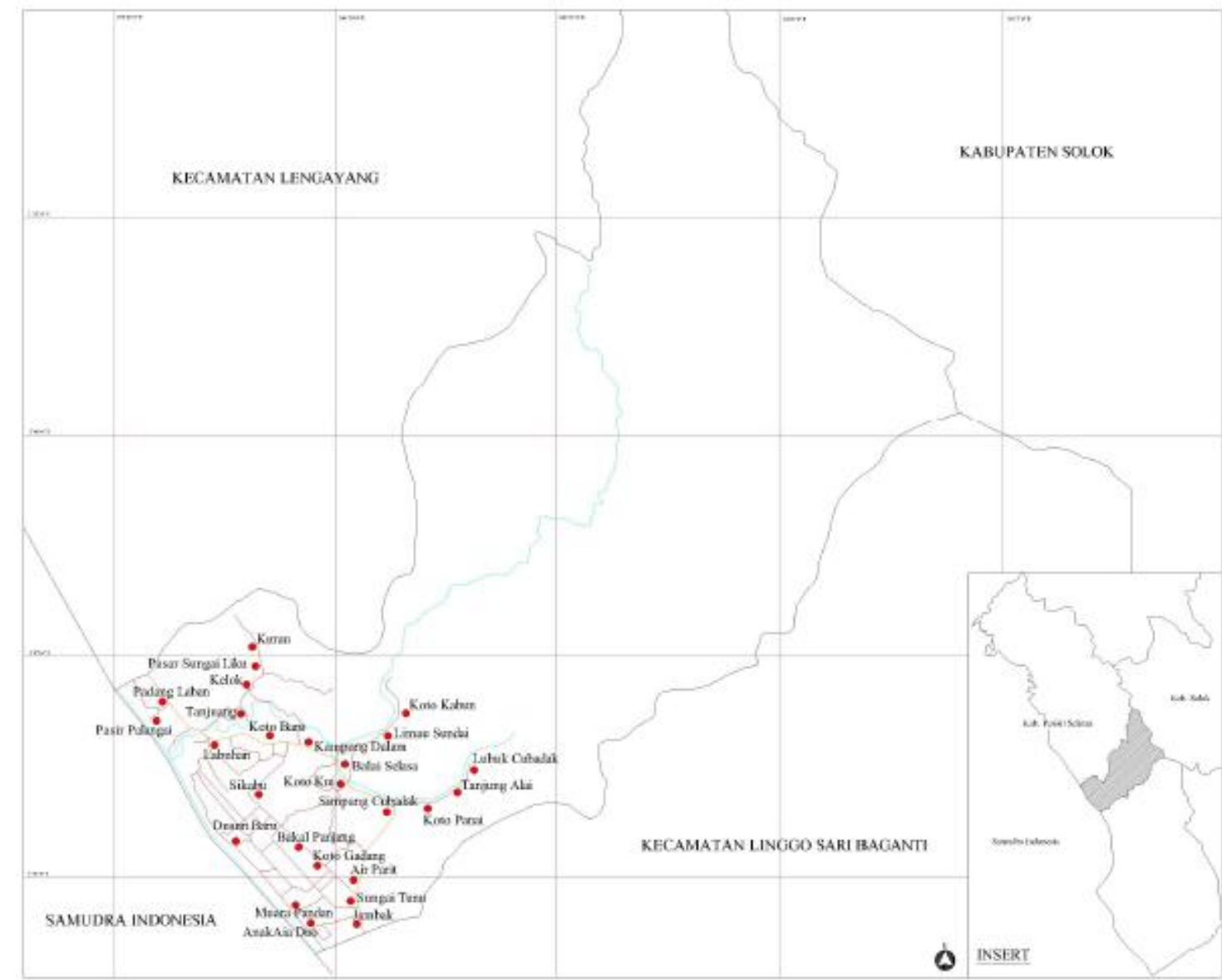

Gambar 1. Peta Administrasi Wilayah Studi

Jumlah penduduk di Kecamatan Ranah Pesisir pada tahun 2011 yaitu 30.404 jiwa yang tersebar di sepuluh nagari, dengan kepadatan 53,43 jiwa/ $/ \mathrm{km}^{2}$. Nagari Koto VIII Palangai merupakan nagari yang paling banyak penduduknya sedangkan Nagari Palangai merupakan nagari yang memiliki penduduk paling padat (Biro Pusat Statistik, 2012).

\section{Profil SPAM Kecamatan Ranah Pesisir}

Sistem Penyediaan Air Minum (SPAM) di Kecamatan Ranah Pesisir terdiri dari sistem perpipaan dan nonperpipaan. Sistem perpipaan dikelola oleh PDAM Kabupaten Pesisir Selatan Unit Balai Selasa dan oleh kelompok masyarakat secara komunal melalui proyek Penyediaan Air Minum dan Sanitasi Berbasis Masyarakat (PAMSIMAS). Sedangkan sistem nonperpipaan dikelola secara individual, seperti Sumur Gali (SG),
Sistem Pompa Tangan (SPT), dan bak Penampungan Air Hujan (PAH) (PU Kabupaten Pesisir Selatan, 2012). PDAM Unit Balai Selasa adalah satu dari 11 (sebelas) unit kantor PDAM Kabupaten Pesisir Selatan. PDAM Unit Balai Selasa terbagi atas dua Instalasi Pengolahan Air Minum (IPAM) yang memanfaatkan sumber mata air yang berbeda. Instalasi tersebut yaitu IPAM Palangai Gadang dan IPAM Palangai Ketek. Daerah pelayanan PDAM Unit Balai Selasa meliputi Pasar Balai Selasa, Koto Kawi, Limau Sundai, Lubuk Cubadak, Tangah Padang, Pacuan dan Labuhan. Tingkat pelayanan sebesar 11,5\% terhadap jumlah penduduk total. Jumlah sambungan terpasang sekitar 1.020 unit sambungan, akan tetapi sambungan yang lancar hanya 372 sambungan dan selebihnya harus menunggu pergiliran air. Angka pemakaian air rata-rata tiap sambungan yang terlayani oleh PDAM sebesar $9 \mathrm{~m}^{3} /$ bulan, 
atau sama dengan $0,3 \mathrm{~m}^{3} /$ hari (PDAM Pesisir Selatan, 2012).

\section{Rencana Tata Ruang Wilayah (RTRW) dan Rencana Induk SPAM (RISPAM)}

RTRW Kabupaten Pesisir Selatan telah disahkan dengan Perda No. 07 Tahun 2011 Tentang RTRW Kabupaten Pesisir Selatan Tahun 2010 - 2030. Berdasarkan keterangan dari dokumen RTRW tersebut, dapat diambil kesimpulan tentang arahan pengembangan Kecamatan Ranah Pesisir dipusatkan pada Nagari Palangai (Bappeda Kabupaten Pesisir Selatan, 2009).

Kecamatan Ranah Pesisir memiliki sumber air baku air minum yang berupa air permukaan Sungai Batang Palangai Gadang dan Sungai Batang Palangai Ketek dengan masing-masing debit minimum $40 \mathrm{l} / \mathrm{dtk}$ dan 20 1/dtk (PU Kabupaten Pesisir Selatan, 2012). Skenario peningkatan pelayanan air minum Kecamatan Ranah Pesisir mengikuti dokumen RISPAM.

\section{METODOLOGI}

\section{Studi Literatur}

Studi literatur bertujuan untuk mempelajari dan memperdalam dasar-dasar teori yang mendukung dalam perencanaan sistem penyediaan air minum. Studi pustaka ini menyangkut peraturan-peraturan yang berlaku dan terkait dengan perencanaan sistem penyediaan air minum.

\section{Pengumpulan Data}

Data-data yang dikumpulkan adalah:

1. Profil daerah Kecamatan Ranah Pesisir

a. Keadaan fisik daerah;

b. Aspek kependudukan;

c. Sarana dan prasarana;

d. Pengukuran lapangan lokasi SPAM.

\section{Profil PDAM}

Data diperoleh dari tinjauan langsung ke lapangan dan ada juga yang diperoleh dari dokumen Rencana Induk SPAM (RISPAM) Kab. Pesisir Selatan tahun 2012. Profil PDAM meliputi komponen sistem penyediaan air minum yang ada yang terdiri dari:

a. Sumber air bersih; b. Cakupan pelayanan;

c. Kuantitas dan kontinuitas pelayanan;

d. Sistem pengolahan air minum meliputi bangunan penangkap, jaringan transmisi, IPAM, reservoar dan jaringan distribusi.

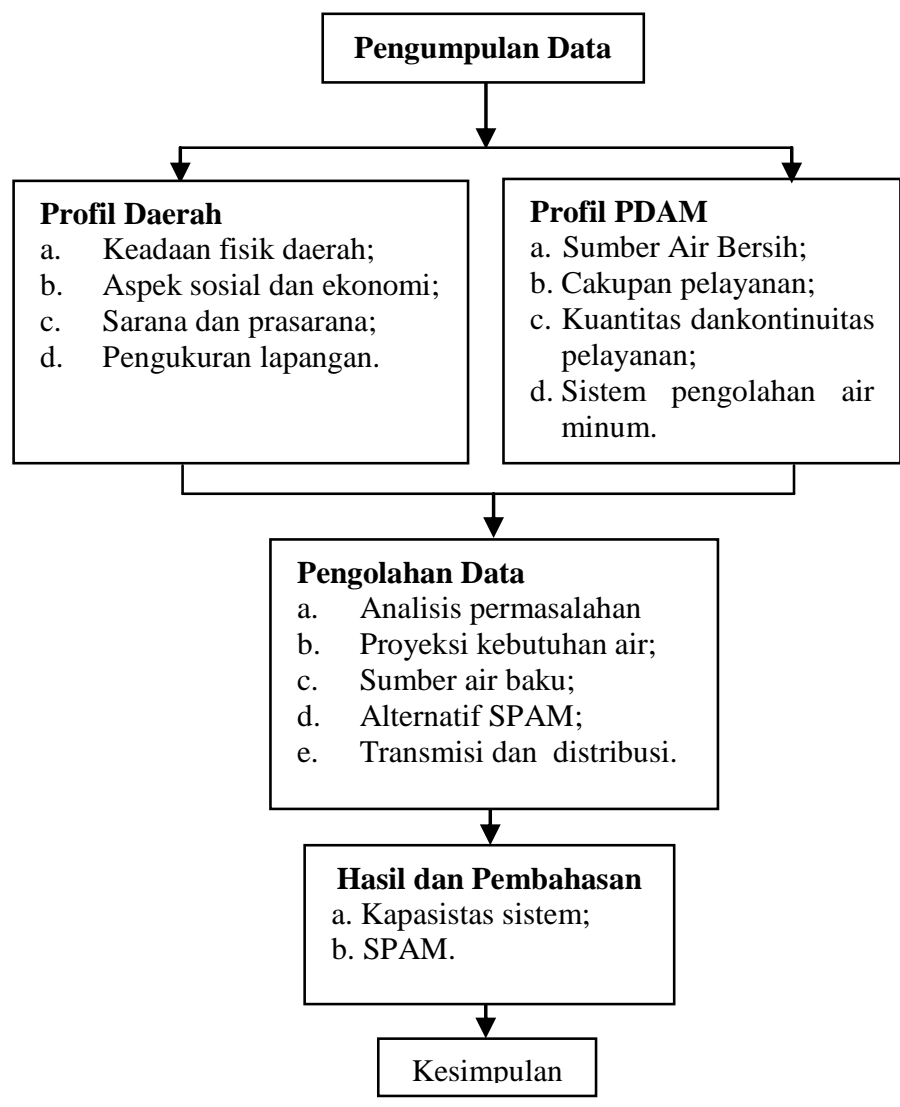

Gambar 2 Bagan Alir Metodologi

\section{Pengolahan Data}

Dari kondisi eksisting yang ada akan dievaluasi berdasarkan peraturan standar materi air minum yang dikeluarkan oleh Departemen Pemukiman dan Prasarana Wilayah tahun 2004. Komponen-komponen SPAM yang dianalisa permasalahannya adalah:

- Sumber air baku

Sumber air baku harus dapat memenuhi kebutuhan air minum yang direncanakan baik dari aspek kualitas, kontinuitas dan kuantitas.

- Jaringan transmisi

Jaringan transmisi dapat mengalirkan air ke bangunan pengolahan sesuai dengan kapasitas yang direncanakan. 
- Bangunan pengolahan

Bangunan pengolahan dipilih sesuai dengan kualitas dan karakteristik air baku. Bangunan pengolahan didesain berdasarkan kriteria perencanaan dan efisiensi pengolahannya.

- Jaringan distribusi

Kebutuhan air minum adalah merupakan penjumlahan dari kebutuhan domestik, non domestik dan kebocoran air. Jenis pelayanan kebutuhan domistik direncanakan menggunakan SR (Sambungan Rumah) dan HU (Hidran Umum) dengan perbandingan 70 : 30 dimana 1 SR melayani 5 orang dan 1 HU melayani 50 orang. Untuk pemakaian air 1 SR direncanakan $90 \mathrm{l} / \mathrm{o} / \mathrm{h}$, sementara untuk $1 \mathrm{HU}$ direncanakan $30 \mathrm{l} / \mathrm{o} / \mathrm{h}$ sampai akhir tahun perencanaan (Dirjen Cipta Karya Dinas PU, 2000). Kebutuhan air non domestik seperti kebutuhan air untuk perkantoran, pasar, dan tempat-tempat umum lainnya diperkirakan sebesar $10 \%$ dari kebutuhan domestik. Kehilangan air menjadi pertimbangan dalam menentukan jumlah debit yang akan dialirkan pada sistem perpipaan. Pada tahun 2010 kebocoran pada sistem perpipaan PDAM Kecamatan Ranah Pesisir sebesar $32 \%$ dan sampai saat ini belum ada perbaikan sistem. Standar tingkat kebocoran minimum yang ditetapkan berdasarkan ketentuan standar pelayanan air minum adalah sebesar $25 \%$.

Faktor pemakaian air terdiri dari faktor pemakaian hari maksimum dan faktor pemakaian jam maksimum (jam puncak). Faktor pemakaian hari maksimum digunakan untuk perencanaan kapasitas pengolahan air minum, sedangkan faktor jam maksimum digunakan untuk memproyeksikan kebutuhan air yang harus disediakan pada jaringan distribusi. Untuk faktor hari maksimum sebesar 1,2 dan faktor jam puncak sebesar 1,5.

Proyeksi kebtuhan air dilakukan untuk periode 17 tahun kedepan dimulai dari tahun 2013 sampai 2030. Penetapan periode proyeksi selama 17 tahun disesuaikan dengan Peraturan Menteri Pekerjaan Umum Nomor 18/PRT/M/2007 tentang Penyelenggaraan Sistem Penyediaan Air Minum yaitu 15-20 tahun. Selain itu juga dengan mengacu pada Rencana Induk
Sistem Penyediaan Air Minum (RISPAM) 2012 dan RTRW 2010 Kabupaten Pesisir Selatan. Sedangkan daerah pelayanan adalah daerah yang mendapatkan pelayanan air minum yaitu meliputi daerah pemukiman dan daerah yang menjadi perencanaan untuk wilayah pemukiman berdasarkan Rencana Tata Ruang Wilayah (RTRW).

Penetapan sumber air baku dilakukan setelah diketahui perkiraan kebutuhan air minum lokasi studi. Hal-hal yang harus dipertimbangkan dalam pemilihan sumber air baku adalah debit air mencukupi terutama pada musim kemarau setelah dipertimbangkan pemanfaatan air lainnya, lokasi sumber cukup ekonomis untuk dimanfaatkan, pencemaran seminimal mungkin, dsb. Setelah menetapkan sumber air baku yang akan digunakan, kemudian dievaluasi alternatif-alternatif pengolahan yang akan digunakan sesuai dengan karakteristik air yang diperoleh.

Penentuan alternatif SPAM meliputi pemilihan jenis bangunan yang akan digunakan, jalur transmisi yang akan direncanakan, unit pengolahan yang diperlukan dan jaringan distribusi sesuai dengan daerah pelayanan. Pemilihan alternatif SPAM tidak terlepas dari aspek ekonomis dan aspek teknis. Sistem transmisi yang dipilih adalah jalur terpendek dan dengan tekanan tertentu dapat mengalirkan air secara gravitasi ke unit pengolahan. Sistem distribusi dipilih berdasarkan pemerataan aliran dan tekanan. Pola pengaliran sistem distribusi dapat berupa pola cabang atau pola loop sesuai dengan kondisi daerah pelayanan. Sistem distribusi mencakup daerah pelayanan yang ditentukan berdasarkan Rencana Tata Ruang Wilayah (RTRW) tahun 2010 yaitu mengutamakan daerah yang menjadi pusat pemukiman dan pusat kegiatan masyarakat kecamatan pada umumnya.

\section{HASIL DAN PEMBAHASAN}

\section{Permasalahan SPAM}

\section{Intake}

Intake Palangai Gadang memiliki kapasitas terpasang 10 l/dtk namun hanya berupa pipa bersaringan yang ditempatkan pada badan sungai tanpa bangunan pelindung. Intake pipa ini sudah sering kali rusak akibat arus 
sungai saat debit sungai mengalami debit maksimum, disamping itu intake ini tidak dapat menangkap air saat debit sungai mengalami penurunan hingga debit minimum. Bak pengumpul yang dimiliki oleh intake sesuai dengan kondisi eksisting sudah tidak dapat digunakan lagi karena kerusakan pada struktur bangunan.

\section{Jaringan Transmisi}

Sistem transmisi eksisting dialirkan secara gravitasi menggunakan pipa GIP dengan diameter $100 \mathrm{~mm}$ dan panjang pipa transmisi sekitar 500 meter. Saat ini, secara keseluruhan jaringan perpipaan transmisi mengalami kerusakan dan perlu adanya perbaikan agar air baku yang ditransmisikan ke unit pengolahan dapat sesuai dengan kapasitas terpasang intake maupun bangunan pengolahan.

\section{Instalasi Pengolahan Air (IPA)}

IPA adalah Saringan Pasir Lambat (SPL) dengan kapasitas 3,5 1/det yang saat ini tidak dioperasikan lagi. SPL tersebut memiliki panjang 15 meter dan lebar 10 meter. SPL ini tidak digunakan lagi karena kerusakan pada struktur bangunan akibat gempa pada tahun 2009.

\section{Reservoar}

Reservoar eksisting memiliki kapasitas 100 $\mathrm{m}^{3}$ yang sudah bocor pada bagian lantai bangunan. Juga terdapat kerusakan lain seperti keretakan pada dinding bangunan akibat gempa sehingga air yang tersimpan hampir sebagiannya terbuang kembali. Pengoptimalan bangunan tidak mungkin dilakukan mengingat perbaikan pada struktur bangunan yang sudah rusak, satusatunya cara adalah membangun reservoar yang baru.

\section{Pipa Distribusi}

Kabupaten Pesisir Selatan masih memiliki tingkat kehilangan air yang tergolong tinggi. Khusus Unit Balai Salasa, tingkat kehilangan air pada tahun 2010 sebesar 32 $\%$. Kebocoran disebabkan karena umumnya perpipaan distribusi mengalami kerusakan baik karena umur pipa yang sudah lama, gempa yang melanda pada tahun 2009 dan juga karena perbuatan taping langsung oleh masyarakat (PU Kab Pesisir Selatan, 2012). Perbuatan taping langsung oleh masyarakat dapat mengakibatkan tekanan pada pipa distribusi menurun sehingga tekanan pengaliran air tidak terpenuhi sampai ke daerah pelayanan.

\section{Tingkat Pelayanan}

Tingkat pelayanannya baru mencapai $11,5 \%$ dari jumlah penduduk Kecamatan Ranah Pesisir. Pipa distribusi saat ini hanya melayani untuk dua nagari yaitu nagari Palangai Gadang dan nagari Palangai. Jumlah sambungan yang ada saat ini sebanyak 1.020 SR (Sambungan Rumah), akan tetapi sambungan yang lancar hanya 372 sambungan dan selebihnya harus menunggu pergiliran air. Jumlah sambungan yang mendapat pergiliran air dapat dihitung yaitu sebesar 648 SR, berarti jumlah air hanya dapat memenuhi setengahnya yaitu 324 SR. Kapasitas air yang didistribusikan dapat dihitung dari jumlah SR yang terlayani semuanya yaitu jumlah SR yang lancar ditambahkan setengah dari jumlah SR yang mendapat pelayanan bergiliran dikalikan dengan asumsi satu SR melayani lima orang dan satu orang dengan debit pemakaian 90 1/hari, sehingga diperoleh debit air yang didistribusikan sebesar $3,6 \quad 1 /$ det. Rekapitulasi permasalahan SPAM eksisting dapat dilihat pada Tabel 1.

\section{Proyeksi Kebutuhan Air}

Berdasarkan RTRW Kabupaten Pesisir Selatan tahun 2010-2030 ditetapkan daerah pelayanan pada daerah pemukiman yang padat penduduk yaitu Nagari Palangai Gadang, Nagari Palangai, Nyiur Malambai Palangai dan Nagari VIII Palangai. Dan berdasarkan RISPAM Kabupaten Pesisir Selatan tahun 2012 dan memperhatikan kemampuan PDAM maka tingkat pelayanan di akhir periode desain direncanakan mencapai $25 \%$. Selanjutnya proyeksi kebutuhan air dapat dihitung sebagaimana ditampilkan dalam Tabel 2. Sehingga didapatkan hasil sbb:

- Kebutuhan air rata-rata 11,84 1/dtk.

- Kebutuhan air maksimum 14,21 1/dtk.

- Kebutuhan air untuk jam puncak $21,31 \mathrm{l} / \mathrm{dtk}$. 
Tabel 1. Rekapitulasi Permasalahan SPAM

\begin{tabular}{|c|c|c|}
\hline No. & $\begin{array}{c}\text { Komponen } \\
\text { SPAM }\end{array}$ & Permasalahan \\
\hline 1 & Intake & $\begin{array}{l}\text { - Daya tangkap air pada musim } \\
\text { kemarau menurun; } \\
\text { - Rusak akibat gempa tahun } 2009 ; \\
\text { - Tidak adanya bak pengumpul. }\end{array}$ \\
\hline 2 & $\begin{array}{l}\text { Jaringan } \\
\text { Transmisi }\end{array}$ & 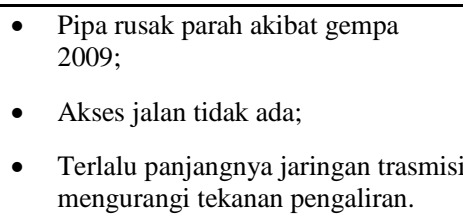 \\
\hline 3 & $\begin{array}{l}\text { Bangunan } \\
\text { Pengolahan }\end{array}$ & $\begin{array}{l}\text { - } \begin{array}{l}\text { Unit pengolahan berupa SPL yang } \\
\text { tidak berfungsi lagi; }\end{array} \\
\text { - } \quad \begin{array}{l}\text { Struktur bangunan SPL rusak parah } \\
\text { akibat gempa tahun } 2009 ;\end{array} \\
\text { - Tidak adanya pencucian filter } \\
\text { karena tidak adanya petugas; } \\
\text { - Air langsung didistribusikan tanpa } \\
\text { adanya pengolahan. }\end{array}$ \\
\hline 4 & Reservoar & $\begin{array}{l}\text { - Lantai bangunan sudah bocor; } \\
\text { - } \quad \text { Keretakan dinding akibat gempa } \\
2009 ; \\
\text { - Perbaikan yang dilakukan hanya } \\
\text { dapat mengatasi kebocoran } \\
\text { sementara; } \\
\text { - Reservoar yang ada merupakan bak } \\
\text { PNPM yang tidak sesuai dengan } \\
\text { standar spesifikasi reservoar. }\end{array}$ \\
\hline 5 & $\begin{array}{l}\text { Sistem } \\
\text { Distribusi }\end{array}$ & 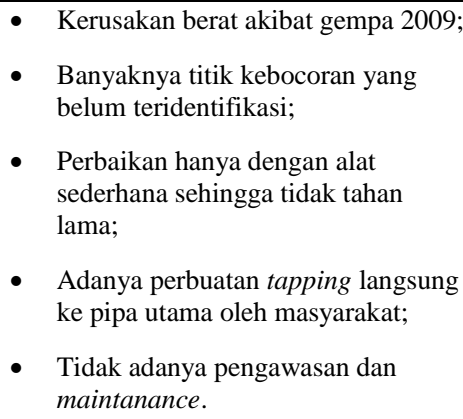 \\
\hline 6 & $\begin{array}{l}\text { Tingkat } \\
\text { Pelayanan }\end{array}$ & $\begin{array}{ll} & \text { Tingkat pelayanan } 11,5 \% \text {; } \\
\text { - } & \text { Pergiliran air yang masih terjadi. }\end{array}$ \\
\hline
\end{tabular}

Sungai Batang Palangai Gadang akan digunakan sebagai sumber air baku karena kualitas air termasuk dalam kelas satu menurut PP No 82 Tahun 2001 sebagaimana disajikan dalam Tabel 3. Debit minimum dari Sungai Batang Palangai 40 1/det. Intake yang direkomendasikan untuk direncanakan adalah intake kanal dengan mempertimbangkan tebing dari sungai yang stabil dan fluktuasi permukaan air sungai tidak terlalu besar, muka air minimumnya sekitar 1,1 m dari dasar sungai pada saat kemarau. Disamping itu juga mengingat intake kanal memiliki konstruksi yang sederhana. Antara intake dan badan air dibatasi dengan dinding beton yang kedap air untuk mencegah terjadinya erosi pada bangunan. Pengaliran dari intake ke bangunan pengolahan secara gravitasi. Intake berkapasitas $15 \mathrm{l} / \mathrm{det}$ dengan jalur transmisi sepanjang $90 \mathrm{~m}$ dengan beda ketinggian $7 \mathrm{~m}$ sehingga dapat dialirkan secara gravitasi.

Tabel 2. Proyeksi Kebutuhan Air

\begin{tabular}{|c|c|c|c|c|c|c|}
\hline \multirow{2}{*}{ Uraian } & \multirow{2}{*}{ Sat. } & \multicolumn{5}{|c|}{ Tahun Proyeksi } \\
\hline & & Eksis & 2015 & 2020 & 2025 & 2030 \\
\hline \multicolumn{7}{|l|}{ Asumsi } \\
\hline$-\mathrm{SR}$ & $1 / \mathrm{j} / \mathrm{hr}$ & 60 & 90 & 90 & 90 & 90 \\
\hline$-\mathrm{HU}$ & $1 / \mathrm{j} / \mathrm{hr}$ & & 30 & 30 & 30 & 30 \\
\hline Kebocoran & $\%$ & 32 & 30 & 25 & 25 & 25 \\
\hline \multicolumn{7}{|l|}{ Kebutuhan Air } \\
\hline $\begin{array}{l}\text { Kebutuhan } \\
\text { Domestik }\end{array}$ & $1 / \mathrm{dt}$ & 3,64 & 6,80 & 8,54 & 8,58 & 8,61 \\
\hline - Pddk terlayani & jiwa & 3496 & 6315 & 7938 & 7971 & 7998 \\
\hline - Kebutuhan SR & $1 / \mathrm{dt}$ & 3,64 & 4,60 & 5,79 & 5,81 & 5,83 \\
\hline - Kebutuhan HU & $1 / \mathrm{dt}$ & 0 & 2,19 & 2,76 & 2,77 & 2,78 \\
\hline $\begin{array}{l}\text { Keb. Non } \\
\text { Domestik }\end{array}$ & $1 / \mathrm{dt}$ & 0,36 & 0,68 & 0,85 & 0,86 & 0,86 \\
\hline Debit Kebocoran & $1 / \mathrm{dt}$ & 1,28 & 2,24 & 2,35 & 2,36 & 2,37 \\
\hline $\begin{array}{l}\text { Total Kebutuhan } \\
\text { Air }\end{array}$ & $1 / \mathrm{dt}$ & 4,01 & 7,48 & 9,40 & 9,44 & 9,47 \\
\hline Kebutuhan rata2 & $\mathbf{l} / \mathbf{d t}$ & 5,29 & 9,72 & $\begin{array}{r}11,7 \\
5\end{array}$ & $\begin{array}{r}11,8 \\
0\end{array}$ & $\begin{array}{r}11,8 \\
4\end{array}$ \\
\hline Kebutuhan Maks & $1 / d t$ & 6,35 & $\begin{array}{r}11,6 \\
6\end{array}$ & $\begin{array}{r}14,1 \\
0\end{array}$ & $\begin{array}{r}14,1 \\
6\end{array}$ & $\begin{array}{r}14,2 \\
1\end{array}$ \\
\hline $\begin{array}{l}\text { Kebutuhan } \\
\text { Puncak }\end{array}$ & $1 / d t$ & $\mathbf{9 , 5 2}$ & $\begin{array}{r}17,5 \\
0\end{array}$ & $\begin{array}{r}21,1 \\
5\end{array}$ & $\begin{array}{r}21,2 \\
4\end{array}$ & $\begin{array}{r}21,3 \\
1\end{array}$ \\
\hline
\end{tabular}

Sumber Air Baku dan Transmisi

\section{Alternatif Unit Pengolahan Air}

Unit pengolahan perlu dibuat baru karena unit pengolahan yang ada yaitu Saringan Pasir Lambat (SPL) tidak mungkin untuk dioptimalkan mengingat kondisi fisik dari bangunan yang sudah hancur dan telah tertimbun tanah. SPL sudah lama tidak beroperasi dan sekarang sudah menjadi tempat menimbun sampah, satu-satunya cara adalah membangun unit pengolahan yang baru. 
Tabel 3. Hasil Uji Sumber Air Baku terhadap PP 82/2001

\begin{tabular}{|c|c|c|c|c|c|}
\hline $\begin{array}{c}\text { No } \\
\text {. }\end{array}$ & Parameter & Satuan & Uji & $\begin{array}{c}\text { PP } \\
\text { No.82 } \\
\text { Kls } 1\end{array}$ & Ket. \\
\hline & Fisika & & & & \\
\hline 1 & TSS & $\mathrm{mg} / \mathrm{l}$ & 11 & 50 & OK \\
\hline \multirow{2}{*}{2} & TDS & $\mathrm{mg} / \mathrm{l}$ & 27 & 1000 & OK \\
\hline & Kimia & & & & \\
\hline 1 & $\mathrm{pH}$ & & 7,25 & $6-9$ & OK \\
\hline 2 & DO & $\mathrm{mg} / \mathrm{l}$ & 5 & 6 & OK \\
\hline 3 & $\bar{P}$ & $\mathrm{mg} / \mathrm{l}$ & 0,074 & 0,2 & $\mathrm{OK}$ \\
\hline 4 & $\mathrm{NO}_{3}$ & $\mathrm{mg} / \mathrm{l}$ & 1,25 & 10 & OK \\
\hline 5 & $\mathrm{NO}_{2}$ & $\mathrm{mg} / \mathrm{l}$ & 0,042 & 0,06 & OK \\
\hline 6 & $\mathrm{H}_{2} \mathrm{~S}$ & $\mathrm{mg} / \mathrm{l}$ & $\mathrm{ttd}$ & 0,002 & OK \\
\hline 7 & Khlorida & $\mathrm{mg} / \mathrm{l}$ & 258 & 600 & OK \\
\hline 8 & Kesadahan & $\mathrm{mg} / \mathrm{l}$ & 216 & & OK \\
\hline 9 & As & $\mathrm{mg} / \mathrm{l}$ & ttd & 0,05 & OK \\
\hline 10 & $\mathrm{Cu}$ & $\mathrm{mg} / \mathrm{l}$ & ttd & 0,02 & OK \\
\hline 11 & $\mathrm{Fe}$ & $\mathrm{mg} / \mathrm{l}$ & 0,154 & 0,3 & OK \\
\hline 12 & $\mathrm{~Pb}$ & $\mathrm{mg} / \mathrm{l}$ & $\mathrm{ttd}$ & 0,03 & OK \\
\hline 13 & $\mathrm{Mn}$ & $\mathrm{mg} / \mathrm{l}$ & 0,088 & 0,1 & $\mathrm{OK}$ \\
\hline \multirow[t]{3}{*}{14} & $\mathrm{Zn}$ & $\mathrm{mg} / \mathrm{l}$ & 0,039 & 0,05 & OK \\
\hline & Biologi & & & & \\
\hline & $\begin{array}{l}\text { Fecal } \\
\text { Coliform }\end{array}$ & $\begin{array}{l}\mathrm{jml} / \\
100 \mathrm{ml}\end{array}$ & 6,1 & 100 & OK \\
\hline 2 & $\begin{array}{l}\text { Total } \\
\text { Coliform }\end{array}$ & $\begin{array}{l}\mathrm{jml} / \\
100 \mathrm{ml}\end{array}$ & 9,7 & 1000 & OK \\
\hline
\end{tabular}

Berdasarkan uji kualitas air baku dengan membandingkan dengan Peraturan Menteri Kesehatan Republik Indonesia No.492/MenKes/PER/IV/2010 sebagaimana disajikan dalam Tabel 4, dapat direncanakan beberapa alterrnatif pengolahan air minum. Parameter yang melebihi standar baku mutu hanya parameter biologi yang dapat diatasi dengan unit pengolahan desinfeksi. Sampel air diambil saat musim kemarau, untuk mengantisipasi peningkatan kekeruhan pada saat musim hujan maka diperlukan unit pengolahan yang dapat menurunkan tingkat kekeruhan. Kekeruhan saat musim kemarau sebesar 3 NTU, peningkatan kekeruhan pada Sungai Batang Palangai saat musim hujan diperkirakan dapat mencapai 5 kali lebih tinggi dari pada musim kemarau, artinya saat musim hujan kekeruhannya dapat mencapai 15 NTU atau paling tinggi 20 NTU.
Alternatif pengolahan yang dapat menurunkan kekeruhan diantaranya ada Unit Prasedimentasi, Unit Saringan Pasir Lambat (SPL), dan Unit Saringan Pasir Cepat (SPC). Unit pengolahan untuk mengatasi tingkat kekeruhan saat musim hujan direncanakan Unit SPC. SPC dipilih dibandingkan SPL dan Prasedimentasi karena beberapa alasan sebagai berikut:

1. Berdasarkan tingkat kekeruhan pada musim hujan yang dapat mencapai 20 NTU maka Unit SPC adalah Unit yang dapat digunakan untuk menurunkan kekeruhan hingga 50 NTU.

2. Unit SPC tidak memakai lahan yang luas seperti pada unit SPL, mengingat ketersediaan lahan di lokasi yang tidak terlalu luas.

3. Unit prasedimentasi memiliki tingkat efektifitas penyaringan lebih rendah dibandingkan dengan unit SPC.

4. Alternatif pengolahan lain yang dapat dilakukan yaitu menggunakan unit Prsedimentasi dan SPL, namun biaya investasi semakin besar seiring dengan semakin banyaknya unit yang digunakan.

Bak filtrasi ini direkomendasikan terdiri dari 2 unit bak dengan kapasitas masing-masing bak sebesar 7,5 1/dtk. Media filter yang digunakan adalah pasir dan antrasit dengan media penyangga adalah kerikil (terdiri dari 4 lapisan). Periode pencucian satu kali 24 jam dengan lama pencucian selama 10 menit. Air untuk pencucian diambil dari reservoar dengan menggunakan pompa.

Untuk proses desinfeksi dengan memakai kaporit/kalsium hipokhlorida $\left(\mathrm{Ca}(\mathrm{OCl})_{2}\right)$ yang diinjeksikan ke dalam pipa sebelum masuk ke reservoar. Kaporit yang digunakan adalah dengan kadar pasaran $70 \%$. Banyaknya klorin yang dibutuhkan untuk setiap pembuatan adalah $0,6 \mathrm{~kg}$ dengan frekuensi pembuatan 2 kali sehari (setiap 12 jam).

\section{Reservoar dan Distribusi}

Reservoar dibangun berada di dekat bangunan pengolahan. Jaringan distibusi dibangun dengan jalur yang baru dan untuk melayani daerah pelayanan yang telah direncanakan. Pengaliran jaringan distribusi secara gravitasi dengan pola cabang karena 
pemukiman penduduk yang berada di sepanjang jalan. Jaringan distribusi harus dilengkapi dengan satu buah jembatan pipa untuk melintasi sungai.

Tabel 4. Hasil Uji Air Baku terhadap Permenkes 492/2010

\begin{tabular}{|c|c|c|c|c|c|}
\hline $\begin{array}{l}\mathbf{N} \\
\text { o. }\end{array}$ & Parameter & Sat & Uji & $\begin{array}{c}\text { Permenkes } \\
492 / 2010\end{array}$ & Ket. \\
\hline & \multicolumn{5}{|l|}{ Fisika } \\
\hline & & & & Suhu Udara & \\
\hline 1 & Temperatur & ${ }^{\circ} \mathrm{C}$ & 26,3 & $\pm 3^{\circ} \mathrm{C}$ & $\mathrm{OK}$ \\
\hline 2 & Warna & TCU & 2 & 15 & $\mathrm{OK}$ \\
\hline 3 & Kekeruhan & NTU & 3 & 5 & $\mathrm{OK}$ \\
\hline \multirow[t]{2}{*}{4} & TDS & $\mathrm{mg} / \mathrm{L}$ & 27 & 500 & OK \\
\hline & \multicolumn{5}{|l|}{ Kimia } \\
\hline 1 & $\mathrm{pH}$ & & 7,25 & $6,5-8,5$ & $\mathrm{OK}$ \\
\hline \multirow[t]{2}{*}{2} & $\mathrm{NO}_{3}$ & $\mathrm{mg} / \mathrm{L}$ & 1,25 & 50 & $\mathrm{OK}$ \\
\hline & & & 0,04 & & \\
\hline 3 & $\mathrm{NO}_{2}$ & $\mathrm{mg} / \mathrm{L}$ & 2 & 3 & $\mathrm{OK}$ \\
\hline 4 & Khlorida & $\mathrm{mg} / \mathrm{L}$ & 207 & 250 & $\mathrm{OK}$ \\
\hline 5 & Kesadahan & $\mathrm{mg} / \mathrm{L}$ & 216 & 500 & $\mathrm{OK}$ \\
\hline 6 & Arsen (As) & $\mathrm{mg} / \mathrm{L}$ & Ttd & 0,01 & $\mathrm{OK}$ \\
\hline 7 & $\mathrm{Cu}$ & $\mathrm{mg} / \mathrm{L}$ & Ttd & 2 & $\mathrm{OK}$ \\
\hline 8 & Besi (Fe) & $\mathrm{mg} / \mathrm{L}$ & 0,15 & 0,3 & $\mathrm{OK}$ \\
\hline \multirow[t]{2}{*}{9} & Timbal $(\mathrm{Pb})$ & $\mathrm{mg} / \mathrm{L}$ & Ttd & 0,01 & $\mathrm{OK}$ \\
\hline & Mn & $\mathrm{mg} / \mathrm{L}$ & $\begin{array}{r}0,08 \\
8\end{array}$ & 0,1 & $\mathrm{OK}$ \\
\hline \multirow[t]{3}{*}{11} & $\mathrm{Zn}$ & $\mathrm{mg} / \mathrm{L}$ & $\begin{array}{r}0,03 \\
9\end{array}$ & 3 & $\mathrm{OK}$ \\
\hline & Biologi & & & & \\
\hline & $\begin{array}{l}\text { Fecal } \\
\text { Coliform }\end{array}$ & $\begin{array}{l}\mathrm{Jml} / \\
100 \mathrm{~mL}\end{array}$ & 6,1 & 0 & $\begin{array}{l}\text { Tida } \\
\text { k OK }\end{array}$ \\
\hline 2 & $\begin{array}{l}\text { Total } \\
\text { Coliform }\end{array}$ & $\begin{array}{l}\mathrm{Jml} / \\
100 \mathrm{~mL}\end{array}$ & 9,7 & 0 & $\begin{array}{l}\text { Tida } \\
\text { k OK }\end{array}$ \\
\hline
\end{tabular}

Reservoar distribusi akan dibangun dengan kapasitas $350 \mathrm{~m}^{3}$. Bangunan reservoar terdiri dari 2 kompartemen yang sama besar. Bangunan ini dilengkapi dengan aksesoris perpipaan seperti: pipa inlet, outlet, drain, overflow, dan water meter untuk mengukur debit air yang dialirkan pada jaringan distribusi (konsumen). Selanjutnya skema SPAM yanag diusulkan dapat dilihat pada Gambar 3.

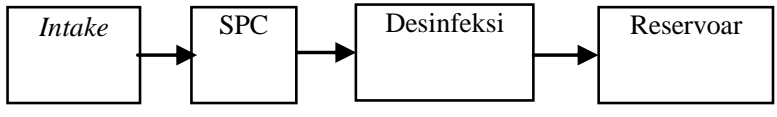

Gambar 3 Skema SPAM Rencana

\section{SIMPULAN}

Intake SPAM Eksisting hanya berupa berupa pipa bersaringan tanpa bangunan pelindung yang mengalami kendala pada musim kemarau.

IPA SPAM eksisting hanya berupa SPL, namun unit ini mengalami kerusakan karena gempa dan tidak beroperasi.

Lokasi studi memerlukan SPAM dengan debit rata-rata 15 l/dtk.

Proyeksi kebutuhan air selama 17 tahun (2013 - 2030) diperoleh bahwa kebutuhan air minum rata-rata, maksimum dan puncak berurutan adalah 11,84 1/dtk, 14,21 1/dtk, dan 21,31 1/dtk.

Sungai Batang Palangai Gadang akan digunakan sebagai sumber air baku karena kualitas air termasuk dalam kelas satu menurut PP No 82 Tahun 2001, dengan menggunakan intake kanal berkapasitas 15 1/dtk. Air baku akan ditransmisikan dengan perpipaan sepanjang $90 \mathrm{~m}$ dengan beda elevasi $7 \mathrm{~m}$ terhadap lokasi IPA.

Pengaliran jaringan distribusi dapat dilakukan secara gravitasi dengan pola cabang karena pemukiman penduduk yang berada di sepanjang jalan.

\section{DAFTAR PUSTAKA}

Biro Pusat Statistik, Kabupaten Pesisir Selatan dalam Angka 2012.

PU Kabupaten Pesisir Selatan, Rencana Induk Sistem Penyediaan Air Minum (RISPAM), 2012

Bappeda Kabupaten Pesisir Selatan, RTRW Kabupaten Pesisir Selatan 2010-2030, 2009)

PDAM Pesisir Selatan, Laporan Teknis 2011, 2012

Ditjend Cipta Karya Dinas PU, Kriteria Perencanaan, 2000 